\title{
'New Wars: Forgotten Warriors': Why Have Girl Fighters Been Excluded from Western Representations of Conflict in Sierra Leone?
}

\author{
Alice Macdonald*
}

Since the end of the cold war, the way we talk about war has changed. Instead of talking about 'noble' inter-state warfare, as was common in the past, there is a new Western vocabulary depicting modern conflict as chaotic and callous. Child soldiers are seen as emblematic element of the 'new wars', yet the presence of girl fighters has been continually ignored by the international community and neglected in academic writing. When girls have attracted attention, it has been purely as victims. Using a case study of Sierra Leone, this essay analyses how the Western representation of girls as victims plays into the Western construction of Africa as a place needful of military and humanitarian intervention. By looking at discourses of gender and youth, I examine how the construction of the girl child is integral to maintaining the myth of the young 'aggressive' African male and the white 'saviour'; both essential for 'new wars' and the humanitarian industry.

The conflict in Sierra Leone has been considered by many academics as a prime example of a 'new war' (Kaplan 1994; Kaldor 2001) and thus lends itself particularly well to the subject under discussion. The emphasis in the West has been on the 'barbarity' and high level of atrocities carried out by combatants ${ }^{1}$ as well as the use of child soldiers. As Rosen points out, it is seen as a 'symbol of the horrors of modern war' (2005:58) and continues to attract media attention, as has done the recent film Blood Diamonds shows. Sierra Leone has also been chosen as a case study because of the high level of female participation in the conflict (Mazurana and Carlson 2004:2) and because of the recognition that girls were failed in the Demobilisation Demilitarization and Reintegration (DDR) process (Coulter 2005), which I shall briefly touch on in this essay, although space limits a more detailed analysis.

* The Mill House, Ringstead Road, Sedgeford, Hunstanton, Norfolk, PE36 5NQ. Email: alicem1983@yahoo.co.uk. 


\section{Rhetoric and Reality: Girl Soldiers in Sierra Leone}

In Sierra Leone, girls made up 25 per cent of the child soldiers and 8 per cent of the total number of fighters (Mazurana and Carlson 2004:3). This is a significant figure, given their invisibility in this conflict. Significantly, Paul Richards points out that 'women figure quite prominently in the leadership of both the NPFL and RUF' (2005:89). Indeed, when male commanders were absent from camps, a high level of responsibility often passed to their 'wives'. For example, it was up to them to decide how food was distributed (Mazurana and Carlson 2004:14).

Although some girls used this level of power to protect the more vulnerable in the camps, girls also committed a high level of atrocities. As Coulter points out 'there has been little or no emphasis on women as fighters and killers' despite the fact that commanders' wives were often in charge of the notorious Small Boys Unit and the lesser known Small Girls Units (Coulter 2005:6). Similarly, the mammy queens were 'some of the most violent and powerful female combatants' (Rosen 2005:70), assuming names such as 'Queen Cut Hands’, Lieutenant 'Cause Trouble’ and Lady ‘Jungle Law’ (TRC 2007:394).

Despite the active role that girls played as fighters, international organisations and NGOs have focused on the girl purely as victims of sexual violence (HRW 2003). For example, in one Human Rights Watch Report, there is little acknowledgment of the active roles girls played in the conflict. The authors note that, 'even within the rebel forces, women still held much lower status' (2003:22). However, as the example of the commanders' wives shows, generalisations of this nature should not be made as some girls held more power than men. Another NGO report also focuses on rape, stating 'In Sierra Leone, young girls in particular were singled out for rape' (PLAN 2007:109). ${ }^{2}$ Similarly the UNIFEM website mentions girls in Sierra Leone only as sex slaves and human shields, rendering them as passive objects rather than subjects.

So, how can we explain this blinkered representation? While assumptions which humanitarian agencies make about age as 'a closed age-bound category of agency-free individuals’ (Utas 2004:211) may explain the lack of representations of violent girls, it is only part of the picture. If this were the case, NGOs would represent girls as reluctant fighters in much the same way as the majority of boy soldiers are configured, but, in fact, they are significantly absent from conversations about war unless it is as victims, as we can see from the case study of Sierra Leone above. Due to their gender and age, girls are the ultimate symbol of victimhood and are thus a powerful advocacy tool for NGOs, journalists and researchers (Nordstrom 1999:18). As McKay points out 'Women and children' rolls easily off network tongues 
because, in network minds..., women are family members rather than independent actors (cited in Karam 2001:19).

Clearly, the idea of the girl soldier is for many an 'impossible oxymoron' (Fox 2004:476); anathema to the traditional Western assumptions about women and warfare. This can be linked to gender stereotyping embodied in the idea of a Western hegemonic masculinity in which masculinity is linked to violence.

As Park states, girls have been 'too visible as super-victims' (2006:316). This representation of girls as victims is an integral part of the political project of war and should not be seen as an inconsequential stereotype.

The 'super-victim' tag was clearly applied in Sierra Leone where girls and women were seen purely as 'camp followers', abducted by the various fighting groups (McKay and Mazurana 2004). In fact, girls carried out a multitude of roles; as cooks, porters, wives, food producers and spies. Furthermore, nearly half of those interviewed by Mazurana and Carlson received basic military and weapons training (2004). Clearly the 'supervictim' tag does not fit the girls in Sierra Leone whose display of agency and rational choice is a far cry from the passive female victim, which the international community prefers to represent. As Arty notes, 'there is a general misconception that the majority of youth were forced to take up arms by the RUF. Whilst this is true for many, many more joined voluntarily' (Peters 2005:275). Significantly, Rosen notes how girls fought 'because of the excitement, power and material gain it (war) offered' (Rosen 2005:87).

The evidence from Sierra Leone thus underlines how the representation of girls is based on predetermined ideas of them as objects not subjects, rather than a rational assessment of reality. Assumptions about gender and the patriarchal nature of the international system mean that the girl fighter is ignored because she does not fit culturally acceptable ideas of how women should behave. The hierarchical submission of female to male, both in the domestic and international sphere, is unfortunately a continued assumption in contemporary society and any attempt to challenge this binary opposition 'threatens the entire system' (Scott cited in True 1996:236).

I take the system highlighted here to be the domain of nationalism to which the issue of girl soldiers can be linked. Gender and nationalism are intricately linked - the idea of the nation state is often based on the idea that the nation is female whilst the state is male. As Nagel points out, the nation 'is a male-headed household in which both men and women have "natural" roles to play' (1998:254). The 'natural' role of men is as protector, whilst that of the female is of 'protected'. The separation of children from war can therefore be understood through the association of the mother figure with 
the nation. The image of the girl soldier would challenge 'the essentialist construction of men as aggressive and violent (that) fits the nationalistmilitaristic myth in which men fight for the sake of the women and children, the "protected-protector myth"' (Yuval-Davis 1999:111). Nationalism is based on the idea that the nation needs to be protected; an image which centres on the nurturing mother or passive female. If this changes and girls are perceived as violent, many of the common tropes and assumptions underlying the concept of nationhood are lost.

Although these assumptions about the cultural roles fitting women and men are common throughout the developed and developing world and can help to explain the invisibility of girls in Sierra Leone, there is another explanation which centres on the constructed image of a 'mythical, culturally and religiously violence-prone Third World' (Hendrixson 2004:15) and is linked to post-cold war security paradigms. The predominant narratives on the Sierra Leonean conflict are emblematic of this.

\section{Aggressive Males, Passive Females, the Interventionist Agenda}

After the end of the cold war, the international system was thrown into a state of flux and the dominant theory of realism was shaken to its core. This inevitably led to new ways to understand conflict. In the contemporary era, two narratives on conflict stand out; 'New Barbarianism' and the underdevelopment paradigm (Duffield 2001).

'New Barbarianism' is based on the idea that cultural differences are the 'origin of antagonism and conflict' (Duffield 2001:109) and has been particularly influential in shaping popular understanding of conflict in Africa. Despite the complexity of the conflict in Sierra Leone, it was the 'New Barbarianism narrative that dominated, as embodied in Robert Kaplan's influential article, 'The Coming Anarchy' (1994), in which Sierra Leone is used as a case study. Kaplan's argument, based on the 'youth bulge’ paradigm referred to later, is that, due to the high number of young men in Africa, conflict is unavoidable (1994:46). His theory presents a monolithic portrait of youth in Africa and refuses to see them as anything other than violent thugs. Sierra Leone's conflict is thus clearly emblematic of the West's conception of Africa's 'uncivil war(s)' (Ferme and Hoffman 2005:88).

By contrast, in the underdevelopment model, the causes of conflict are the 'modalities of underdevelopment and its associated pathologies of crime and terrorism' (Duffield 2001:114). In this model, 'new wars' provide an opportunity for liberal developmentalists to prove their utility, but depend on the existence of a helpless victim. 


\section{The Spectacle of Humanitarianism}

The overt racism of 'New Barbarianism' can be found more subtly in developmentalist discourse, which makes the same assumptions about superiority and inferiority. For example, Robert Kaplan believes that 'only when people have attained a certain economic, educational and cultural standard is this trait (propensity to violence) tranquilised' (Kaplan cited by Duffield 2001:115). The international human rights regime adopts a similar belief in its attempt to introduce 'universal' human rights worldwide. Both models therefore pave the way for Western intervention - whether military or humanitarian.

International development agencies adopt the idea that underdevelopment necessitates Western intervention to achieve Western 'standards'. Attitudes towards women and girls in the third world, their so-called 'oppression' are often seen as emblematic of this kind of underdevelopment. ${ }^{3}$ By representing the girl child as a victim, agents of liberal developmentalism can claim the power to deal with them paving the way for the insertion of Western liberal values into often completely different cultures.

In their representations of girls in the developing world, humanitarian organisations create an 'other' who is silenced and has no power. Girls are not analysed as individuals, nor given the space to express their own opinion on conflict and their role within it, but rather become part of the 'bureaucratization of knowledge about the third world' (Escobar 1995:106). This permits a certain institutionalisation of them as passive bodies who are acted upon. The ability to protect the girl child is seen as criteria for establishing who needs the help of the 'civilised' West, thus the maintenance of the girl victim is a way to ensure 'an alibi for humanitarian action' (Debrix 1999:142). Paradoxically, this does not always have the desired positive effect. For example, in Sierra Leone this misunderstanding of the complex roles girls played in the conflicts had direct negative repercussions on their reintegration into society. Despite their presence in the fighting forces, only a very low percentage of girls went through the DDR programmes, usually run by international agencies (McKay and Mazurana 2004:20).

In a perceptive comment, Tony Brauman observes how 'This emptying out of interiority to the benefit of its exterior signs, this exhaustion of the content by the form....is at the basis of humanitarianism as a spectacle' (cited in Debrix 1999:136). His comment emphasises how humanitarianism must be seen as an ideology which selects the images that fit its own goals and objectives, often to the detriment of the individual. In this case, it is the experiences of the girl fighter that has been lost within a set of discourses, which refuse to see her as an active agent. 


\section{The Youth Bulge}

If we now turn to 'New Barbarianism', we find another narrative that is fundamental in understanding the construction of the passive female: 'the youth bulge'.

The youth bulge refers to an unusually large population of 15-24-year-olds relative to the adult population (Goldstein 2002:11) who predominantly live in the global South. Instead of representing the 'hope of the nation', this young population are pejoratively seen as a 'demographic ticking time bomb' (ibid), which will inevitably trigger conflict. This is particularly significant in relation to security paradigms, as 'the state needs threats, a degree of insecurity in order that it generates security' (Brocklehurst 2006:153). The youth bulge is therefore a way to ensure that the West's security identity is maintained. Furthermore, employing the youth bulge to explain intrastate conflict means that it is easier to ignore other factors, for example the neo-liberal agenda, in influencing peace and security in Africa.

One may ask how this paradigm is relevant to the invisibility of girl combatants. As Yuval-Davis points out, 'Womanhood is a relational category' and must be examined in the context of notions of both 'manhood' and 'womanhood' (1997:1). Whilst the unstable elements present in this picture are assumed to be young men, the image of the passive girl, in fact, plays a crucial role in the maintenance of these stereotypical images, as she serves as a counterpart to and reinforces the image of the aggressively heterosexual young man (ibid:10). Strategies of interventionism and 'otherness' are clearly linked as intervention is not possible without an 'other'- this other can either be the weak victim who will be 'saved' by the powerful or the barbaric 'other' who can only be defeated by the 'civilised'.

There is concrete evidence of the youth bulge paradigm in Sierra Leone where the economic approach, which focuses on how youth affects war rather than how war affects youth, was adopted by organisations such as USAID and the World Bank in the DDR programmes (Kemper 2005:11). Indeed, tellingly, according to Paul Collier, director of the Research Group of the World Bank from 1998 to 2003, 'the true cause of much civil war is not the loud discourse of grievance, but the silent force of greed' (ibid: 35), one of the key messages of the 'new wars' paradigm.

The World Bank's approach thus fits the youth bulge analysed earlier, in which young men 'are considered more prone to violence than women' (ibid: 26). Consequently, the priority is to focus on men in order to avoid a return to conflict. As Coulter (2006) notes in relation to the DDR programmes, 'Male fighters were also high on the priority lists of both government and aid agencies as they were perceived to be a real threat to peace and stability'. 
This demonstrates a tendency to sacrifice the individual to the collective as the assumption, that girls are biologically pacifist and men are by nature aggressive, persists. Aid programmes focus on those most likely to pose a threat to stability. As such, a kind of cost-benefit analysis is done resulting in the marginalisation of a large section of the population, particularly women and girls.

Another area of which Sierra Leone is emblematic is the tendency to hold up the protection of women's rights as a reason for intervention in other countries. For example, in an interview in 2001, first lady Laura Bush stated that 'The fight against terrorism is also a fight for the rights and dignity of women' (ibid: 10). Hendrixson rightly identifies the underlying message as 'white men saving brown women from brown men' (ibid). This is clearly true of the war in Sierra Leone. In a telling passage of the Truth and Reconciliation commission reports, it states that

'women and girls are shunned and punished by members of a society who refuse to acknowledge that it is their failures that led to this conflict and their failure to protect women and girls that has led to the plight they find themselves in today' (2007:2). ${ }^{4}$

The implicit subtext here is clear; 'society' refers to the men whose job it is to protect women, which implies that women and girls are helpless without the intervention of men. As these men in these countries are seen as weak, external intervention is therefore justified.

This is a common message in the 'new wars' literature; according to one author, 'the purposeful starvation of women and children in Somalia and the random execution of uncovered women in Algeria are all acts of atrocity difficult to imagine civilized people committing' (Snow 1996:145, emphasis added). In a similar vein, the narrative of the 'barbarity' of men in the developing world is clearly demonstrated by Ignatieff when he states: 'the particular savagery of war in the 1990s taps into another vision of male identity - the wild sexuality of the adolescent male' (1998:127). The rampant sexuality of the African male was a common trope of colonialism and the quotes above clearly demonstrate how narratives on the developing world have evolved very little. ${ }^{5}$

By denying women and girls agency and depicting them as innocent and passive victims, men in Africa are turned into aggressors. This allows foreign intervention (humanitarian or military) as the African state is seen as incapable of controlling the young who are believed to be 'prone to criminal behaviour, petty theft, drugs, drunkenness and anti-social tendencies' (Abdullah 2005:180). This relates to the idea of war as a political construction in which women and children are 'considered innocent in the war-constructed contexts 
of rationality and irrationality’ (Nordstrom 1997:1) Whilst young men in the third world are considered irrational because of a predisposition to violence, girls are denied a position altogether, relegated to objects to be manipulated for political purposes.

Thus, girl combatants are neglected in representations of war because they challenge the clearly defined picture of civility versus barbarity that a certain powerful faction in the West prefers to promote.

It is therefore clear that the 'new wars' mantra has stripped wars of their social content (Richards 2005:17) and reduced the actors to cardboard cutouts of perpetrators and victims, facilitating Western intervention. Whilst I do not wish to dismiss the suffering that girls obviously do experience in war, we must read beyond this and deconstruct these discourses as part of a political project. The emergence of individual agency threatens discourses of victimhood. As such, there is a clear, if subconscious gain in suppressing them and maintaining the symbolic collective tropes of victimhood, which ensures ‘othering' as part of interventionism.

\section{Conclusion}

There are many factors preventing an accurate portrait of the roles girls played in the Sierra Leonean conflict. Gender stereotyping with its emphasis on the victim has played a key role in this respect. However, whilst it is important to apply a gender lens to all situations, this cannot be employed in isolation and other discourses of race, ethnicity and age. Girls are clearly appropriated for a range of purposes: the construction of the aggressive African 'other' or the construction of the white liberator.

The predominant narrative of 'savage warfare', which characterises much discourse on civil conflicts in the developing world, has had a consequential effect on attitudes towards girls. Michael Ignatieff comments that, 'Intolerant people are uninterested in the individuals who compose despised groups; in fact they barely see "them" as individuals at all. What matters is the constitution of a primal opposition between "them" and "us"” (1998:63). Ignatieff's comments can easily be applied to the situation of girls in Sierra Leone, whose individual experiences and agency were ignored in favour of a homogenised picture, which assumed the singular experience of girls in war. Indeed, collectivism has come to characterise much of the approach of the international community, leading to an arrogant application of Western stereotypes about the 'barbarity' of the South. The idea that girls may be fighters as well as victims challenges the black and white ideas of conflict in Africa that many in the West hold. As such, the image is intentionally or subconsciously repressed, much to the detriment of the empowerment of women that many in the West claim to advocate. 


\section{Notes}

1. As Richards has shown, the causes of conflict were not straightforward, he demonstrates how many of these barbaric acts were actually based on rational calculations. For example, the use of amputations can be seen as a message to civilians not to vote.

2. PLAN is a large international development NGO focusing specifically on children.

3. See for example the debate on female genital mutilation which, although perceived as a barbaric practice by many Western agencies, has been defended on the basis of cultural difference.

4. Although the TRC was supported by UNHCR, UNDP and UNAMSIL this report was produced by the Sierra Leonean government, perhaps indicating the introduction of Western values. Unfortunately given limited space a comparative study of African and Western representations of girls and conflict is not feasible but is an interesting area for further research.

5. Further evidence for this is Kaplan's statement that 'West Africa is reverting to the Africa of the Victorian atlas' (1994:47).

\section{References}

Abdullah, I, 2005, “'I am a Rebel”: Youth Culture and Violence in Sierra Leone', in Honwana and F De Boeck (eds.), Makers and Breakers: Children and Youth in Postcolonial Africa, Oxford: James Currey, pp.172-187.

Brocklehurst, H., 2006, Who's Afraid of Children? Children, Conflict and International Relations, Hampshire: Ashgate.

Collier, P., 2000, 'Doing Well out of War: An Economic Perspective', in Berdal M. and D. Malone (eds.), Greed and Grievance: Economic Agendas in Civil War, Dakar/Ottawa/ Cairo Lynne Rienner, pp. 91-110.

Coulter, C., 2005, 'The Post-War Moment: Female Fighters in Sierra Leone', Migration Studies Working Paper Series 22, accessed on http:// migration.wits.ac.za.

Debrix, F., 1999, Re-envisioning Peacekeeping: the United Nations and the Mobilisation of Ideology, Minneapolis: University of Minnesota Press.

Duffield, M., 2001, Global Governance and the New Wars, London/New York: ZED.

Elshtain, J., 1995, Women and War, Chicago: University of Chicago Press

Escobar, A., 1995, Encountering Development: the Making and Unmaking of the Third World, Princeton: Princeton University Press.

Ferme, M. and Hoffman, D., 2005, 'Hunter Militias and the International Human Rights Discourse in Sierra Leone and Beyond', Africa Today, 50, Summer, pp. 73-95.

Fox, M-J., 2004, 'Girl Soldiers: Human Security and Gendered Insecurity', Security Dialogue, 35 (4), pp. 465-479.

Goldstein, J.S., 2001, War and Gender, Cambridge: Cambridge University Press. 
Hendrixson, A., 2004, 'Angry Young Men, Veiled Young Women: Constructing a New Population Threat', Corner House Briefing 34, accessed on 27 June 2007, http://www.thecornerhouse.org.uk/summary.shtml?x=85999

Human Rights Watch, 2005, Youth, Poverty and Blood: the Lethal Legacy of West Africa's Regional Warriors, Vol. 17 (5), London: HRW.

Human Rights Watch, 2003, We'll Kill You if You Cry: Sexual Violence in the Sierra Leone Conflict, 15 (1), London: Human Rights Watch.

Huntington, S., 1993, 'The Clash of Civilisations', Foreign Affairs, 72 (3), pp. 22-49.

Ignatieff, M, 1998, The Warrior's Honor: Ethnic War and the Modern Conscience, London: Chatto and Windus.

Kaldor, M., 2001, New and Old Wars, Cambridge: Polity Press.

Kaplan, R., 1994 'The Coming Anarchy: How Scarcity, Crime, Overpopulation and Disease are Rapidly Destroying the Social Fabric of our Planet', Atlantic Monthly, Vol. 273 (2), pp. 44-76.

Kemper, Y., 2005, 'Youth in War to Peace Transitions: Approaches of International Organizations', Berghof Report 10, accessed on 17 July 2007 at

http://www.reliefweb.int/rw/lib.nsf/db900SID/OCHA-6REE3X/\$FILE/berghof-genjan05.pdf?OpenElement

Mazurana, D. and Carlson, K. (eds.), 2004, 'From Combat to Community: Women and Girls of Sierra Leone', accessed on 23/07/07 at

http://www.smallarmssurvey.org/files/portal/spotlight/disarmament/disarm_pdf/ 2004_Mazurana_Carlson.pdf

McKay, S. and Mazurana, D., 2004, Where are the Girls? Girls in Fighting Forces in Northern Uganda, Sierra Leone and Mozambique: Their Lives During and After War, Montreal International Centre for Human Rights and Democratic Development.

McIntyre, A., 2005, Invisible Stakeholders: Children and War in Africa, Pretoria: Institute for Security Studies.

Nagel, J., 1998, 'Masculinity and Nationalism: Gender and Sexuality in the making of nations', Ethnic and Racial Studies 21 (2), pp. 242-269.

Nordstrom, C., 1997, Girls and War Zones, Troubling Questions, Uppsala: Life and Peace Institute.

Nordstorm, C., 1999, 'Visible Wars and Invisible Girls: Shadow Industries and the Politics of Not-Knowing', International Journal of Feminist Politics, Vol. 1, pp. 14-33.

Park, A.S.J., 2006, ““Other Inhumane Acts”: Forced Marriage, Girl Soldiers and the Special Court for Sierra Leone’, Social and Legal Studies, 15 (3), pp. 315-337.

Peters, K. and Richards, P., 1998, 'Why We Fight: Voices of Young Combatants in Sierra Leone’, Africa, (68), pp. 183-211.

PLAN international, 2007, Because I am a Girl: The State of the World's Girls, London: Plan.

Richards, P., (ed.), 2005, No Peace, No War, Oxford: James Currey.

Richards, P., 1996, Fighting For the Rainforest: War, Youth and Resources in Sierra Leone, London: James Currey. 
Rosen, D., 2005, Armies of the Young: Child Soldiers in War and Terrorism, New Brunswick: Rutgers University Press.

Snow, D. M., 1996, Uncivil Wars: International Security and the New Internal Conflicts, Boulder: Lynne Rienner.

Shepler, S., 2002, 'Les filles-soldats: Trajectoires d'après guerre en Sierra Leone', Politique Africaine 88, pp. 49-63.

True, J., 1996, 'Feminism' in S. Burchill and A. Linklater (eds.), Theories of International Relations, New York: St Martin’s, pp. 231-276.

Truth and Reconciliation Commission (TRC), 2007 'Women and the Armed Conflict in Sierra Leone'.

UNIFEM, accessed on 30 July at, www.unifem.org

Utas, M., 2004, 'Fluid Research Fields: Studying Excombatant Youth in the Aftermath of the Liberian Civil War', in Boyden J. and J. de Berry, Children and Youth on the Front Line, New York: Bernhahn, pp. 209-237.

Yuval-Davis, N., 1997, Gender and Nation, London: Sage.

Zalewski, M., 1995, 'Well, What is the Feminist Perspective on Bosnia?', International Affairs, 71(2), pp. 339-356. 
